\title{
The State-Religion Amendment to the Constitution of Bangladesh: A Critique
}

\author{
By Shah Alam
}

\section{Introduction}

The Constitution Eighth Amendment Actl passed by Jatiya Sangsad, the Parliament of Bangladesh, on 9 June 1988 has, inter alia, introduced Islam as the state religion of Bangladesh. A new clause as Article $2 \mathrm{~A}^{2}$ has been inserted in the Constitution incorporating this part of the Act. This has caused substantial damage to the secular character of the Constitution of Bangladesh putting the members of the minority communities i.e., Hindus, Christians and Buddhists, in an unequal position in relation to the Muslims. The result has been a serious undermining of the concept and character of the state of Bangladesh and tampering with the basic structure of her Constitution.

Proclamation of a particular religion as state religion of Bangladesh is contrary to the consciousness that guided her people in their struggle for independence. This has posed a threat to the ideals which as derivatives of this consciousness were enshrined in the Constitution of Bangladesh adopted by the Constituent Assembly on 4 November 1972 as the solemn expression of the will of the people. 3 The proclamation has also put at stake some of the fundamental rights of the citizens guaranteed by the Constitution. Result has been a change in the basic features and structure of the Constitution providing sufficient grounds for questioning the legality of the act responsible for this change.

This paper seeks to examine the constitutionality of the Eighth Amendment to the Constitution of Bangladesh so far as it relates to declaration of Islam as state religion of the country. Before examining the legal aspects of the problem, efforts have been made to make a historical and socio-political evaluation of the issues involved. Legal questions are tested on the touchstone of relevant historical facts and socio-political reality.

1 Act No. XXX of 1988, The Bangladesh Gazette, 9 June 1988.

2 The Article 2 A states that "the state religion of the Republic is Islam, but other religions may be practised in peace and harmony in the Republic."

3 For the Constitution-making process, see Moudud Ahmed, Bangladesh: Era of Sheikh Mujibur Rahman, University Press Limited, Dhaka, 1983, pp. 90-135. 


\section{Constitutional Amendments in Bangladesh}

The question of constitutional amendments has always been a subject of great controversy. This controversy has acquired added dimension and intensity in the countries where the working of the constitutional process has never been smooth and where the power is often usurped in different forms. This is very typical of the developing countries where governments are often changed through extra-constitutional means generally by military coups d'Etat. Bangladesh in her short history of nineteen years already presents a typical Third World pattern of constitutional amendments made from time to time not to improve the constitution but to tailor it to the needs of the incumbents to keep them in power. 4

Since the enactment of the Constitution of Bangladesh in 1972, nine amendments to it have been made. Of them, the Fourth5, Fifth6 and Eighth Amendments provokes serious dissension and discontentment among the people leading to widespread protests, both violent and non-violent. While various political parties and organisations continued to oppose the amendments and fought for their repeal, the amendments themselves, with two notable exceptions 7 , survived. Eighth Amendment has been a sort of culmination of the whole process of tampering with the Constitution of Bangladesh making it a helpless victim of corruptionist power politics, political hypocrisy, instability and military interference in the govemance of the state.

Had the incumbent-governments repealed or completely rejected the prevailing constitution and ruled the country totally on the basis of physical force issuing orders and proclamations whenever necessary or by manufacturing their own constitutions, the problem of amendments and the question of their constitutionality would not have arisen at all. But the

4 "Nine Amendments in 17 years: Original Character of the Constitution Changed", The Bangladesh Observer, 9 July 1989, p. 1.

5 The Fourth Amendment which was passed on 25 January, 1975, introduced Presidential form of government changing the parliamentary system and imposed an authoritarian one-party rule in the country.

6 The Fifth Amendment passed on 6 April, 1979, inserted a new Aricle 18 in the fourth schedule of the Constitution incorporating all martial law proclamations, regulations, orders and ordinances made during the period from August 15, 1975 to April 9, 1979 including all amendments by way of additions, modifications, substitutions and omissions made in the Constitution and barred them from court jurisdiction. Notable amongst them were a retum to multi-party system, deletion of secularism from the Constitution as one of the fundamental principles of state policy and reposing absolute trust and faith in the Almighty Allah.

7 As stated above in note 6, the Fifth Amendment revived the multi-party system which had to give way to one-party rule under the Fourth Amendment. Part of the Eighth Amendment so far as it related to creation of six extra permanent benches of the High Court Division of the Supreme Court of Bangladesh outside the capital city of Dhaka was declared void by a recent Judgement of the Supreme court of Bangladesh (infra). 
incumbents have always tried to give semblance of the authority of the original Constitution as a source of moral and legal strength. Coming to power through extra-constitutional means, the incumbents have always tried to take advantage of the authority of the fundamental law of the land depriving it at the same time of its true essence. These they have done by the operation of various amendments. Eighth Amendment is one of the most controversial of them.

\section{The Eighth Amendment}

The Eighth Amendment passed by the Parliament of Bangladesh has incorporated two fundamental changes in the Constitution: (i) Islam was made the state religion of Bangladesh by way of insertion of Article $2 \mathrm{~A}$ in the Constitution and (ii) Article 100 of the Constitution was so amended as to change the character of the Judiciary i.e., in addition to the High Court Division of the Supreme Court of Bangladesh with its permanent seat in the capital city of Dhaka, six more permanent benches of the High Court Division were created in different places of the country with exclusive territorial jurisdiction. These changes not only led to volley of protests throughout the country, they also caused several writ petitions 8 to be filed in the High Court Division of the Supreme Court challenging the constitutional validity of these changes. State-religion part of the impugned Eighth Amendment has been challenged on the ground that it grossly interferes with the character of the state itself as well as it puts at stake some of the fundamental rights of the citizens guaranteed by the constitution while creation of six permanent benches of the High Court Division outside the capital was alleged to have broken the integrity, oneness and cohesion of the Highest Seat of Justice creating thereby scopes for multiple standard of justice. Both these changes under the impugned Amendment were argued to have covered and adversely affected more Articles of the Constitution than purported. Their effect has been to change the basic structure of the Constitution.

8 Three writ petitions separately by Mr. Anwar Hossain (C.P. No. 207 of 1988), Mr. Jalaluddin (C.P. No 208 of 1988) and Mr. Ibrahim Sheikh (C.P. S.L. No. 3 of 1989) were filed in the High Court Division challenging the validity of the Eighth Amendment so far as it related to the creation of six extra benches of the High Court Division, while three more writ petitions, one by Nari Pokkha, a social organisation for the defence of Women's rights (W.P. No 1330 of 1988), one by Citizens' Committee for Resisting Communalism and Autocracy and another one by Mr. Shakti Das Goswami (W.P. No. 1177 of 1988) were filed challenging the state-religion part of the impugned Amendment. 


\section{Historical and Socio-Political Test of the Eighth Amendment}

Formally speaking, there may be nothing wrong in having a state religion. At present as many as forty six countries of the world do have state religions. 9 But their validity and purposefulness are explained by historical and social reasons in contradistinction with any motivation of political nature. Mention may be made here of the Constitution of Pakistan for its relevance to our study. The 1973 Constitution of Pakistan10 as renovated by the former President General Ziaul Haque on 29 March 1987 declares Islam as the state religion of Pakistan. This may not be considered an unusual case as it is bome out by the history of emergence of Pakistan and her constitutional development.11 The earlier constitutions of Pakistan $(1956,1962)$ proclaimed Pakistan as an Islamic Republic. 12 This was in consonance with the ideals on the basis of which Pakistan was created. Notably Pakistan was curved out of British India as a Muslim state in realisation of the demands of the Muslims for a separate homeland in the Indian Subcontinent. 13 Naturally so, inclusion of a provision in a Pakistani Constitution (1983) that renamed Republic of Pakistan as Islamic Republic of Pakistan may not be considered an unusual act.

Situation in Bangladesh presents a different picture. More than $15 \%$ of her population are non-Muslims and the independence of the country itself was the result of a secular and democratic movement. 14 Bangladesh, a monolithic nation-state of the Bengalees, has a long tradition of her people living in communal peace and harmony. They have always uphold the values of their ethnic culture and language alongside with their religious beliefs not allowing one to devour the other. Though there have been unfortunate breaches in this tradition, under pressure from various artificially created forces and factors, during Indian independence and partition of the Subcontinent in 1947, the people of this part of the Subcontinent, as subsequent developments proved, remained true to their non-communal tradition.

9 "The Arrival of the Eighth Amendment", Dhaka Courier, vol. 4, Issue - 41, 15 May 1988, pp. 8-9.

10 The 1973 Constitution named Pakistan as Republic of Pakistan while the previous two Constitutions used the name Islamic Republic.

11 Freeland Abbot, Islam and Pakistan, Comell University Press, Ithaca, New York, 1968, p. 183; G. W. Chowdhury, Constitutional Development in Pakistan, Longman, London, 1969, pp. 35-58; G. W. Chowdhury, Pakistan: Transition from Military to Civilian Rule, Scorpion Publishing Lud., Essex, 1988, p. 77; Constituent Assembly of Pakistan Debates, vol. V, March 7, 1949, p. 3.

12 Moudud Ahmed, op. cit., p. 93; K. M. Subhan, "Constitutionalised Religion", Dhaka Courier, vol. 4, Issue - 41, 15 May 1988, p. 23.

13 See below note 15.

14 K. M. Subhan, op. cit., pp. 23-24. 
British India was divided in 1947 on the basis of two-nation theory ${ }^{15}$ propagated by Muslim League, the political party exclusively for the Muslims. The Congress propagating a secular line of thinking failed to ensure the unity of India. Result was creation of two independent states - India and Pakistan. Pakistan comprised two Muslim majority regions situated more than a thousand miles one from the other with India between them. This was a geographical rarity and a child of communal politics spearheaded by vested interest groups. The real motives of partition of India on religious line lay in the idea of protecting the interests of the rising Muslim bourgeosie who considered a separate state for the Muslims to be a safe home for their economic power.

After independence, religion became the centre-piece in the politics of Pakistan. Islam became an instrument of exploitation, especially regional exploitation, exploitation of the Eastem wing of Pakistan (East Pakistan which later became Bangladesh) by the Western wing, a phenomenon reminiscent of the colonial past. 16

Attack by the Pakistani ruling circles was first of all directed against the traditional culture and language of the Bengalees. Bengali language which was the language of the majority of the people of Pakistan was planned to be eliminated from national life and Urdu be imposed on a Bengali speaking community. This was fiercely resisted by the Bengalee patriots. They foiled all ill designs of the ruling circles, but only at the cost of blood. Many lives fell victim to the indiscriminate firing by the Pakistani police who disparately tried to crush what has been termed since then as the "Great Language Movement".17 Bengali consciousness was aptly stirred by this incident and the people of Eastem wing basically non-communal in nature realised the consequences of religion being used as instrument of politics.

History of Pakistan upto 1971 is mainly the history of military rules with religion as its propellor, prime means of governance. 18 As a region, former East Pakistan was worst sufferer of this long undemocratic rule. Whenever discontentment and protests were sighted amongst the people of this region, they were always drastically crushed on the pretext of

15 Two nation theory propounded that British India primarily consisted of two separate nations, markedly different one from the other, based on two major religious communities of the sub-continent - Hindus and Muslims. The theory made strong plea for the Muslims for the creation of two separate states - India and Pakistan - based on religion.

16 Kabir U. Ahmed, Breakup of Pakistan, The Social Science Publishers, London, 1972, pp. 34-51; A. M. A. Muhith, Bangladesh: Emergence of a Nation, Bangladesh Books Intemational Ltd., Dhaka, 1978, pp. 73-116.

17 Rounaq Jahan, Pakistan: Failure in National Integration, Oxford University Press, Dhaka, 1973, pp. 43-44; Anthony Mascarenhas, The Rape of Bangladesh, Vikas Publications, Delhi - London, 1971, pp. 16-17.

18 See Tariq Ali, Can Pakistan Survive?, Penguin Books, 1983, 237 p. 
saving Islam and ensuring the unity of Pakistan allegedly in danger from the spontaneous growth of Bengalee culture, literature and language. But the nationalist, secular and democratic forces under the leadership of Sheik Mujibar Rahman from the main opposition party Awami League went ahead and by the end of sixties seriously shook the poison-tree of military dictatorship of Pakistan.19 The military rule of President Ayub Khan was replaced by the military rule of General Yahia Khan who arranged for the first ever General Elections of Pakistan on the basis of "one man, one vote". Awami League won all but two seats from East Pakistan which earned them an absolute majority in the National Assembly of Pakistan. So far as East Pakistan was concerned it was a complete victory for the secular and democratic nationalist forces. 20 But only after this massive victory, Pakistan's ruling masters started showing their real colour.

The results of the General Elections could not be accepted by the ruling cliche and the National Assembly (Parliament) of Pakistan was not convened. On various pretexts, the ruling circles of Pakistan decided not to hand over power to a majority rule of Bengaleedominated Awami League. Instead they went in for a barbarous military crackdown. For long they exploited the religious sentiments of the people, hoodwinked their opinion, confused them, divided them on various issues and ultimately invoked religion in order to unleash a genocidal onslaught on the people of this region.21 This led to the Liberation War of Bangladesh. Achieving human dignity and economic well-being necessitated a bloody war of liberation.

Liberation War of Bangladesh was imbued with high ideals of nationalism, secularism, democracy and socialism. Participation in the Liberation War was universal. Members of the minority communities - Hindus, Christians, Buddhists and others - fought shoulder to shoulder with their Muslim brothers against Pakistani Army. More than a million people had to lay down their lives before an independent Bangladesh could be created. This was a complete rejection of the two-nation theory on which Pakistan was built.

It was only too natural that the high ideals for which the Liberation War was fought would be inshrined in the Constitution of independent Bangladesh as the basic principles of state policy.22 One of these principles was secularism. It was the bitter experience of communalism and the abuse of religion by autocratic rulers that had led to a national consensus as to the imperative need to ensure that in independent Bangladesh there should be an abolition of communalism in all its forms, renunciation of abuse of religion for political purposes and

19 Rounaq Jahan, op. cit., pp. 186-188; A. M. A. Muhith, op. cit., p. 122.

20 Anthony Mascarenhas, op. cit., pp. 53-58, 65.

21 Bangladesh Documents, Vol. I \& II, ed. by S. K. Singh and others, Publications Division, Ministry of Information and Broadcasting, Govemment of India, New Delhi, 1971, pp. $345-445$ (vol. I), pp. 64-68 (vol. II); Anthony Mascarenhas, op. cit., pp. 111-120.

22 Moudud Ahmed, op. cit., p. 93. 
the elimination of discrimination between person and person on the basis of religion. This consensus was reflected in the original contract i.e., the 1972 Constitution of Bangladesh. This is one of the basic features of the Constitution which nobody is empowered to tamper with. Introduction of Islam as state religion in Bangladesh, therefore, contradicts one of the basic features of the Constitution of Bangladesh as well as the spirit that inspired her people in the national liberation struggle.

Constitutionality of any amendment must be tested not only by the amendment provisions of the constitution but, when necessary, also by historical facts and prevailing socio-political reality that give validity to any constitution. Historical facts also become relevant when the moral authority of a constitution is sought for. State-Religion Eighth Amendment to the Constitution of Bangladesh completely fails these tests of its constitutionality.

Reactions to the State-Religion Amendment, therefore, were very sharp and immediate. Various political parties were united in opposing the amendment. Protests, both violent and non-violent, took place throughout the country. Awami League, the largests political party of Bangladesh, vowed to cancel the amendment if retumed to power. Begum Khaleda Zia, the leader of another major party, BNP, commented that the amendment would divide the nation and hence was undesirable. 23

Members of various minority communities of Bangladesh expressed their profound anxiety and did their utmost to impress upon the members of the general public and the Government about the dangerous consequences of such an amendment. The statement made by the Joint Committee of Hindus, Christians and Buddhists soon after the Eighth Amendment Bill was introduced in the Parliament of Bangladesh testified to the situation that the members of the minority communities were feeling threatened.24 Similar concern was expressed by these communities and various sections of the people in innumerable letters, statements, representations made to the Government. In an open letter to the then President of Bangladesh, the Chairman of Bangladesh Hindu Oikya Front said:

"... the recently introduced State-Religion Bill has created a very intense reaction among all sections of people in Bangladesh. Hindus, Muslims, Buddhists and Christians of this land have been nourished in the same cultural heritage since time immemorial. Even the two-nation theory was finally dismissed through the independence war in 1971. Declaration to make Islam the State-Religion of the country 18 years after its independence directly goes against the values and principles of the nation. The harmonious relationships between all the different communities are already suffering badly due to the introduction of this Bill. Several incidents at Durgapur of Mymensingh,

23 Chaka Courier, vol. 4, Issue - 44, 10 June 1988, pp. 9-10.

24 Ibid., vol. 4, Issue - 42, 27 May 1988, p. 3. 
Dinajpur and few other places prove our apprehension. The situation will only serve to bring evil for the people of Bangladesh ..."25

\section{Constitutional Test of the Eighth Amendment}

Sharp reactions to the Eighth Amendment acquired juridical form in a series of writ petitions filed in the High Court Division of the Supreme Court of Bangladesh challenging the validity of the Amendment.26 Writ petitions were directed against two main parts of the Amendment: (i) creation of seven permanent benches of the High Court Division in various parts of the country with exclusive territorial jurisdiction in place of existing one High Court Division of the Supreme Court with permanent seat in the capital city of Dhaka, (ii) declaration of Islam as the state religion of Bangladesh.

Writ petitions relating to the creation of six extra benches of the High Court Division were summarily rejected by the High Court Division. Thereupon appeals were made to the Appellate Division of the Supreme Court. The Appellate Division in its now famous Judgement of 2 September 1989 found the relevant part of the impugned amendment ultra vires of the Constitution and declared it invalid. The Judgement restored the amended Articles 100 and 107 of the Constitution to their original positions. 27

The above Judgement of the Supreme Court of Bangladesh is likely to revolutionise the constitutional development of Bangladesh, if it is not hindered by any extra-constitutional means as it has been the case in the past. Notably during the last nineteen years nine amendments were made to the Constitution of Bangladesh. 28 None of them other than the impugned one was challenged in any court of law. The writ petitions challenging the constitutionality of the Eighth Amendment and the judgement given on them by the highest court of justice have now created new awareness on the law of amendment. Its immediate effect shall fall on the most controversial part of the impugned amendment itself i.e., declaration of Islam as state religion of Bangladesh which has also been challenged in the court and the proceedings on which are now pending in the High Court Division of the Supreme Court (supra).

25 Ibid., vol. 4, Issue - 43, 3 June 1988, p. 24.

26 See above note 8 .

27 For the full text of the Judgement see Constitution Eighth Amendment Case Judgement (Anowar Hossain Chowdhury and others vs. Bangladesh), Vol. IX (A), BLD (Spl) I, Dhaka, 1989.

28 After the impugned Eighth Amendment, another amendment, the Ninth, was passed by the Parliament of Bangladesh in July 1989. This has made provision for holding elections of the President and the Vice-President simultaneously. It has also restricted the President's tenure in of fice for two consecutive five-year terms. 
Ratio decidendi of the Judgement of the Appellate Division of the Supreme Court of Bangladesh is that the legislative organ of the state cannot by way of amendment alter the basic structure or any basic feature of the constitution. Natural corollary to this is that amending power of the parliament is not unlimited. This power has its implied or inherent limitations.29 Any amendment involving change in the basic features or structures of the constitution to be valid under the amendment provisions of the Constitution of Bangladesh must be sent to the people (i.e., referendum) for their assent (Art. $1421 \mathrm{~A}$ ). This mandatory provision was not adhered to in the case of the impugned Eighth Amendment. 30

There are certain basic structural pillars and features in the Constitution of Bangladesh whose absence would negate the true face and fundamental philosophy of the Constitution and hence cannot be amended merely by an act of the Parliament. One such pillar of the Constitution of Bangladesh is the highest seat of judiciary, its oneness and integrity, as manifested in the organisation of the Supreme Court with its two Divisions - High Court and Appellate. Under the impugned amendment High Court Division as integral part of the Supreme Court was dismantled and seven separate benches with exclusive territorial jurisdiction were created in its place. This tantamounted to fragmentation of the highest court which not only caused substantial damage to one of the pillars of the constitution but also ran counter to the unitary character of the state of Bangladesh.

\section{Points of Law Established by the Judgement of the Supreme Court of Bangladesh}

Hearings on the appeals of the writ petitions challenging the validity of the Eighth Amendment so far as it related to the creation of seven separate permanent benches of the High Court Division continued for over two months. 31 Some of the outstanding legal brains of the country most passionately and meticulously made their submissions in order to establish the thesis that in written constitutions there are certain provisions, written or implied, which are considered basic and whose negation would negate the constitution itself and hence cannot be amended. Amendment does not mean destruction. Any amendment by way of addition, alteration, substitution or repeal which would tantamount to destruction of the constitution in part or in full is to be void. The arguments went on to establish that the

29 The Bangladesh Case Reports (Special Issue on 8th Amendment Judgement), Vol. IX, January 1989, p. 1.

30 Article 142 ( $1 \mathrm{~A})$ states that "... when a Bill ... which provides for the amendment of the Preamble or any provisions of Article 5, 8, 48, 56, 58, 80, $29 \mathrm{~A}$ for this Article, is presented to the President for Assent, the President, shall, within the period of seven days after the Bill is presented to him, cause to be referred to a referendum the question whether the Bill should or should not be assented to". For full implications of this Article see below notes 34, 35, 36, and 17.

31 From 19 June 1989 to 23 August 1989 in the Appellate Division of the Supreme Court of Bangladesh. 
amendment of Articles 100 and 107 destroyed one of the structural pillars of the constitution i.e., judiciary as conceived in the original Constitution of Bangladesh. Arguments of the Counsels for the petitioners were confirmed by the judgement of the court that followed.

Submissions of the leamed Counsels and the opinions of the Honourable Judges raised and resolved some very fundamental questions of Constitutional Law in general and the Constitutional Law of Bangladesh in particular i.e., "Supremacy of the constitution", "Status of the preamble in a constitution", "basic features or basic structure of the constitution", "unamendability of basic features", "constitutional doctrine of repugnancy", "parliamentary sovereignty", "constituent and legislative power of the parliament", "amending power of the parliament", "implied or inherent limitations of the amending power" and "the rule of law".

Dr. Kamal Hussain, the leamed Counsel appearing for the appellants argued:

"The amending power under Article 142 is a power under the Constitution and not above and beyond the Constitution and is not an unlimited power. Any power of amendment under Constitution is subject to limitations inherent in the Constitutions. The structural pillars or basic features of the Constitution established by framers of the Constitution cannot be altered by the simple exercise of amending power. The contention that Parliament has unlimited power of amendment is inconsistent with the concept of supremacy of the Constitution which is expressly embodied in the Preamble and Article 7 and is undoubtedly a fundamental feature of our Constitution. Power to amend does not extend to destroying the Constitution in any of its structural pillars or basic structure. The doctrine of basic structure has been developed by the Indian Supreme Court in some cases." (Ref.: Kesavananda's case, AIR 1973 SC 1461; Smt. Indira Gandhi's case, AIR 1975 SC 2299: Sanjeev Coke, AIR 1983 SC 239)32

Leamed Counsel appearing for the appellants in establishing the validity of their thesis laid utmost importance on the Preamble, Articles 7 and 8 of the Constitution of Bangladesh 33 and stressed the requirement of a special procedure i.e., referendum to be followed under Art. 142 (1 A) for their amendment.

32 Constitution Eighth Amendment Case Judgement, Vol. IX (A), BLD (Spl) I, Dhaka 1989, p. 27.

33 Preamble, inter alia, declares, "... it shall be a fundamental aim of the state to realise through the democratic process ... a society in which the rule of law, fundamental human rights and freedom, equality and justice, political, economic and social will be secured for all citizens."

Aricle 7 states: "(1) All powers in the Republic belong to the people, an $\mathrm{d}$ their exercise on behalf of the people shall be effected only under, and by the authority of, this Constitution. (2) This Constitution is, as the solemn expression of the will of the people, the supreme law of the Republic, and if any other law is inconsistent with this Constitution that other law shall, to the extent of the inconsistency, be void." 
Analysing the virtues of the Preamble Barrister Syed Ishtiaq Ahmed, another learned Counsel for the appellants said:

"A Preamble is 'a key to open the mind of the makers' showing the general purposes for which they made the several provisions of the Constitution. The Preamble is not only a part of our Constitution, it having once been amended is now unalterable under Article 142 without referendum. ... Among others, the Preamble (a) declares a pledge to establish through democratic process a society in which 'rule of law, fundamental human rights and freedom, equality and justice' will be ensured and (b) affirms the sacred duty to maintain the 'supremacy of the Constitution'."34

Barrister Ahmed goes on to assert that "these points are so real that they have found a new habitat in the body of the Constitution itself as substantive provisions (Article 7 and 8)."35 Analysing the attribute of Article 7, Barrister Ahmed says:

"... it provides for (a) Sovereignty of the people and the Republican character of the state and government, (b) limited govermment with three organs performing functions by and under the authority of the Constitution, (c) separation of powers between three co-ordinate organs of the state as a corollary of designated functions; (d) supremacy of the Constitution as the solemn expression of the will of the people; (e) voidability of other laws inconsistent with the supreme law (this Constitution) and (f) as a corollary, enforceability of the supremacy of the Constitution by the Supreme Court in the exercise of its plenary judicial power. ... For us the 'basics' and 'fundamentals' of the Constitution exist in the most real, tangible form in Article 7 itself and are further delineated in the body of the Constitution as these leave Article 7 and break, through Fundamental Principles and Fundamental Rights, into channel of co-ordinate organs of the Republic. Article 7 is the 'Pole-Star' which contains the fundamental premises of democratic govemment to which the people had pledged in the Preamble and the principles as expressed in and derived from this Article are so basic and fundamental that Article 7 is unalterable and beyond change." 36

Barrister Ishtiaq Ahmed further added:

"Concept of unlimited amending power as constituent power is opposed to Article 7 because (i) Article 7 described the Constitution as the supreme law and, therefore, an amendment of the Constitution cannot be anything more than a law in the sense the Constitution is; (ii) voidability of law on ground of inconsistency under Article 7 must

34 Constitution Eighth Amendment Case Judgement, op. cit., p. 28.

35 Ibid.

36 Ibid., pp. 28-29. 
include amending law, otherwise that provision in Article 7 will be redundant as an ordinary law inconsistent with the Constitution is void even without the provision of Article $7 ; \ldots$ (iv) an amending law becomes part of the Constitution only of it is a valid law and there cannot be a valid amending law if it comes within the mischief of Article 7. ... Article 7 being basic and fundamental is unalterable and is an express limitation on the amending power." 37

Before pronouncing the judgement on the Eighth Amendment so far as it related to the changes in the judiciary, the Honourable Judges of the Supreme Court gave their learned opinions on the questions of basic features of the Constitution of Bangladesh and their unamendability. Some citations from these opinions are given below.

Justice Badrul Haider Chowdhury said in his judgement that "the power to frame a constitution is a primary power whereas a power to amend a rigid constitution is a derivative power derived from the constitution and subject at least to the limitations imposed by the prescribed procedure."38 Justice Chowdhury further observed:

"... the contention of all the Counsels appearing for the appellants is grounded on the Preamble of our Constitution which even the Parliament cannot amend without referring to the people nor can the Parliament amend Article 8 without referendum. Article 7 stands between the Preamble and Article 8 as statue of liberty, supremacy of law and rule of law and to put in the words of the American Judge quoted to Mr. Syed Ishtiaq Ahmed (appearing for the petitioners) that it is the pole star of our Constitution ... No Parliament can amend it because Parliament is the creation of this Constitution and all powers follow from this Article, namely, Article 7."39

Commenting on the question of basic structure of a Constitution, Justice M. H. Rahman observed in his judgement:

"The doctrine of basic structure is one growing point in the constitutional jurisprudence. It has developed in a climate where the executive, commanding an overwhelming majority in the legislature, gets snap amendments of the Constitution passed without a Green Paper or White Paper, without eliciting any public opinion without sending the Bill to any select committee and without giving sufficient time to the members of the Parliament for deliberations on the Bill for amendment." 40

37 Ibid., pp. 30-31.

38 Ibid., p. 83, para. 145.

39 Ibid., p. 93, para. 183, 184.

40 Ibid., p. 169, para. 435. 
About the soundness of the concept of basic structure of the Constitution and the implied limitations of the amending power of the Parliament Justice Shahabuddin Ahmed pointed out:

"Main objection to the doctrine of basic structure is that it is uncertain in nature and is based on unfounded fear. But in reality basic structures of a Constitution are clearly identifiable. Sovereignty belongs to the people and it is a basis structure of the Constitution. There is no dispute about it, as there is no dispute that this basic structure cannot be wiped out by amendatory process ... If by exercising the amending power people's sovereignty is sought to be curtailed it is the constitutional duty of the Court to restrain it and in that case it will be improper to accuse the court of acting as 'super-legislators'. Supremacy of the Constitution as the solemn expression of the will of the people, Democracy, Republican Govt., Unitary State, Separation of Powers, Independence of Judiciary, Fundamental Rights are the basic structures of the Constitution. There is no dispute about their identity. By amending the Constitution the Republic cannot be replaced by Monarchy, Democracy, by Oligarchy or the Judiciary cannot be abolished, although there is no express bar to the amending power given in the Constitution ... I think the doctrine of bar to change of basic structure is an effective guarantee against frequent amendments of the Constitution in sectarian or party interest in countries where democracy is not given any chance to develop." 41

The arguments of the learned Counsels in the case of the impugned Eighth Amendment as confirmed by the opinions of the Honourable Judges established the following points of law:

1. In the Constitution of Bangladesh there are certain basic features, express or implied, which cannot be amended without referring them to the people i.e., except by way of referendum.

2. The Preamble of the Constitution of Bangladesh has the force of substantive law and is fundamental in character.

3. The Preamble is the touchstone for measuring the validity of an amendment and when the Parliament cannot by itself amend the Preamble, it cannot do the same in relation to any other provision of the Constitution that incorporates the ideas of the Preamble.

41 Ibid., p. 156, para. 377. 
4. Article 7, which incorporates the ideas of the Preamble and which has been termed as the pole-star 42 of the Constitution of Bangladesh, cannot be amended without referring it to the people.

5. Amending power of the Parliament is not an original power but a derivative of the Constitution and hence it is a power within and not beyond the Constitution.

6. Amending power as a derivative power cannot be unlimited in nature.

7. Amending power has its own inherent or implied limitations and can never be interpreted as to destroy the Constitution.

8. Doctrine of repugnancy i.e., inconsistency with other provisions of the Constitution has relevance for the validity of any amendment.

9. In the countries of written constitutions, if there is anything supreme, it is neither the Parliament nor the Judiciary nor the Executive, it is the Constitution.

\section{The Judgement and its Implications for the State-Religion Part of the Eighth Amendment}

Validity of the state-religion part of the Eighth Amendment is to be examined by the ratio decidendi of the decision given by the Appellate Division of the Supreme Court on the Impugned Amendment so far as it related to fragmentation of the High Court Division and creation of seven permanent benches. The fundamental question is whether insertion of a clause declaring Islam as state religion has caused substantial damage to any basic feature of the Constitution of Bangladesh or whether this insertion has adversely affected any other provisions of the Constitution having relation to basic feature or structure of the Constitution. Positive findings of any investigation seeking answer to this question would automatically invalidate the Impugned Amendment. Since the judgement of the Supreme Court has the effect of judicial precedent having law-creating force, a mass of constitutional issues involving various amendments, past, present and future, may come for consideration.

As mentioned earlier, there have been as many as nine amendments to the Constitution of Bangladesh. First seven, at least two of them (4th and 5th) seriously affecting the basic structure of the Constitution, were never challenged in the court of law. Consequently, they became part of the Constitution by people's general acquiescence. In the case of Golak Nath v. State of Punjab (AIR 1967 SC 1643), the Indian Supreme Court found three past

42 See above note 36 . 
amendments of their Constitution invalid on the ground of alteration of the basic structures, but refrained from declaring them void in order to prevent chaos in the national life and applied Doctrine of Prospective Invalidation for the future. This means that the Impugned Amendment can be challenged in the ground that it has altered the basic structure of the Constitution of Bangladesh. That the past amendments were not challenged is no argument refraining one from challenging any present or future amendment affecting basic features or structures. 43

The Impugned Eighth Amendment has some reference to the Fifth One which inter alia deleted secularism as one of the fundamental principles of state policy. Instead it inserted the clause "absolute trust and faith in the Almighty Allah" as one of the fundamental principles of state policy.44 Exclusion of secularism as one of the principles of state policy and inclusion of "absolute trust and faith in the Almighty Allah" naturally created impression of the Constitution tilting towards a position where a particular religion i.e., Islam would become dominating and its teachings would tend to exert pressure on the basic structure of the Constitution. This notwithstanding the Constitution remained as a whole democratic and secular in spirit. But superimposition of Islam in the Constitution as state religion, as it has been done under the impugned amendment, has undermined the whole democratic and secular structure of the Constitution. Mere declaration of faith in the Almighty Allah, one of the Islamic names for God as it has been done under the Fifth Amendment, and naming Islam as state religion under Eighth Amendment is not one and the same thing and does not lead to similar legal consequences for other provisions of the Constitution.

Focal point of all arguments refuting state-religion amendment is again the Preamble of the Constitution of Bangladesh which proclaims a pledge to build "a society in which the rule of law, fundamental human rights and freedom, equality and justice, political, economic and social, will be secured for all citizens". This spirit of the Preamble has been transfused through so many veins of the body of the Constitution, primarily manifesting itself in the declared principles of state policy (Article 8), fundamental rights (Articles 26-44), Republicanism (Article I) and Separation of powers and the supremacy of the Constitution (Article 7). The Preamble is unalterable except by way of referring it to the people and so is unalterable anything having adverse effect on the rule of law; the Preamble is unalterable and so is unalterable anything having adverse effect on fundamental human rights, freedom and equality of the citizens. Declaration of Islam as state religion is an encroachment on the rights of those whose religion is not Islam. More than 15 million people in Bangladesh fall within this category. 45 This is incompatible with the law of equality of all citizens as enshrined in the Preamble.

43 Constitution Eighth Amendment Case Judgement, op. cit., p. 140.

44 See above note 6.

45 K. M. Subhan, op. cit., pp. 23-24. 
The rule of law is not a mere catch-word in the Constitution of Bangladesh but has substantive legal content and is fed by relevant provisions in the main body of the Constitution. Presence of a religion as state-religion is alien to these provisions and is bound to adversely affect them as they are based on a value-system completely different from that of one of religion. Such presence will overshadow the values of democracy and secularism in interpreting various provisions of the Constitution and is likely to pave the way for the enactment of laws with bias in favour or against some particular community or communities.

The spirit of democracy, rule of law and secularism illuminates through the whole body of the Constitution of Bangladesh. It is so real and vibrant that declaring any religion as statereligion negates the whole creation of the Constitution. It is the negation of the finest achievement of the people's struggle for freedom.

The Constitution of Bangladesh is an autochthonous document.46 It has not been imposed upon by any outside power but has originated from a Constituent Assembly that could sit as people's forum only after millions had sacrificed their lives. Those sacrifices were made for a cause, for certain ideals, for certain values which as the sacred will of the people found abode in the Constitution framed by the Constituent Assembly in 1972. Certainly those ideals, and they were first of all ideals of democracy and secularism, history has the record, formed the basic features of the Constitution of Bangladesh. They have taken roots from the soil of the country and blood of he people. They cannot be changed.

\section{Conclusion}

The Eighth Amendment to the Constitution of Bangladesh so far as it relates to the proclamation of Islam as the state religion of the country is alien to the spirit of the Liberation War of Bangladesh which alone gave the country independence and a constitution. The validity of any constitutional amendment must, therefore, be tested on the touchstone of that spirit translated into certain provisions of the Constitution as its basic features. The Constitution as the solemn expression of the will of the people and as the embodiment of the ideals of their struggle for independence cannot be amended in its basic features by a mere act of the Parliament. Any amendment involving change in the basic features of the Constitution can only be effected by referring it to the people i.e., by way of referendum. This mandatory requirement for amendment which is set forth in the Article 142 (1 A) of the Constitution of Bangladesh was not adhered to in the case of the impugned Eighth Amendment which has caused changes in the basic features of the Constitution and, hence, is ultra vires and invalid. 
The Judgement of the Appellate Division of the Supreme Court of Bangladesh on the writ petitions challenging the validity of the Eighth Amendment so far as it related to the creation of several permanent benches of the High Court Division in place of one with its seat in the capital city of Dhaka47 is a land-mark in the constitutional history of Bangladesh. It has established the doctrine of basic features of the Constitution and has also set limits on the power of the Parliament to amend these features. Parliament derives its power of amendment from the Constitution and hence it is a power within the Constitution and not beyond it. Its power of amendment, therefore, cannot be unlimited to the extent of destroying the basic features of the Constitution. The amending power given to the Parliament of Bangladesh under Article 142 is not meant to undermine the basic features and structures of the Constitution.

Proclamation of Islam as state religion is contrary to the democratic and secular commitments of the Constitution of Bangladesh which form parts of its basic features. It also contradicts some of the fundamental rights i.e., equality of all citizens before and equal protection of them under law irrespective of cast, creed, religion and sex, guaranteed by the Constitution. These contradictions render the impugned amendment so far as it relates to proclamation of Islam as state religion of Bangladesh untenable in law.

47 See above p. 8 and f.n. 27. 
The article focusses on three main aspects: Firstly, the author gives a brief account on the scientific background necessary to understand the scope of the problem and some examples of the national and international legislative reactions. The second part deals with the decisions taken at the London Meeting and with the changes to the Montreal Protocol. Finally, the results are considered with respect to their possible medium and long term implications.

\section{The State-Religion Amendment to the Constitution of Bangladesh: A Critique}

\section{By Shah Alam}

In 1988, the parliament of Bangladesh passed the Eighth Constitutional Amendment Act introducing Islam as the state religion. This act put an end to the constitutionally guaranteed equality between Muslims and Hindus, Christians and Buddhists. The implications of this constitutional amendment reach far, as it stands in contradiction to the consciousness and the ideals of the struggle for independence, which have been included in the 1972 constitution of Bangladesh. As the amendment collides with fundamental rights of the citizens still guaranteed by the constitution, there is sufficient ground for questioning the legality of the act underlying this change.

The basis for examining the constitutionality of the Eighth Amendment to the Constitution of Bangladesh regarding the declaration of Islam as the state religion is formed by a historical and socio-political evaluation of the issues involved. Legal questions are tested on the touchstone of relevant historical facts and socio-political reality. The author comes to the conclusion that the proclamation of Islam as the state religion is in contradiction to the spirit of the liberation war which formed the foundation of both independence and the constitution. He contends that a mere act of parliament is sufficient to change the provisions of the constitution that embody the ideals of the struggle for independence. Any amendment involving change in the basic features of the constitution can only be effected by referring it to the people, i.e. by way of referendum. This mandatory requirement for amendment which is set forth in Art. 142 (1 A) of the constitution was not adhered to in the case of the impugned Eighth Amendment and it is, hence, ultra vires and invalid. 